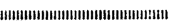 技術報告

\author{
岩㴊 義孝*.波多野隆司*.竹之内朋夫*2 \\ 吉本一夫*. 宮本 剛汎*2
}

\section{Corrosion Resistance and Mechanical Properties of 17Cr-5Ni-1Mo Cast Steel for Hydraulic Runner}

\author{
Yoshitaka Iwabuchi, Takashi Hatano, Tomoo Takenouchi, \\ Каzиo Үоsнiмото, and Takehiro Мгунмото
}

\begin{abstract}
Synopsis :
In order to develop a new hydraulic runner casting with a good corrosion resistance, studies have been carried out on some properties of several $\mathrm{Cr}-\mathrm{Ni}$ martensitic stainless cast steels. The properties of a partial model runner casting of the developed $17 \mathrm{Cr}-5 \mathrm{Ni}-1 \mathrm{Mo}$ steel were investigated. The results are as follows.

1. Internal quality of this casting is superior and comparable with that of $13 \mathrm{Cr}-\mathrm{Ni}$ type casting in terms of cavity and macrosegregation.

2. Excellent corrosion resistance is performed by higher chromium content and $1 \%$ molybdenum addition.

3. Charpy impact properties are almost same as those of $13 \mathrm{Cr}-1 \mathrm{Ni}$ casting. This is attributed to delta ferrite.

4. Enhanced fatigue strength stems from higher corrosion resistance and tensile strength.

5. This casting also possesses good weldability.
\end{abstract}

\section{1. 緒言}

13Cr-1Ni (ASTM CA-15) および 13Cr-4Ni (ASTM CA6NM) で代表される低炭素 $13 \mathrm{Cr}-\mathrm{Ni}$ 系マルテ ンサイトステンレス鋳鋼は, 高強度, 靶延性, キャビテ ーションエロージョン性能が得られることから水車ラン ナー材として広く用いられている1) 3) 反面, オーステナ イト系ステンレス鋼よりも耐食性および腐食瘦労強度は 劣るものであつた.

一方，欧州に拈いて約 20 年前から使用されてきた $16.5 \mathrm{Cr}-4 \mathrm{Ni}$ 系マルテンサイトステンレス鋳鋼は, $\mathrm{Cr}$ 量 を高めたことによつて耐食性が问上すると報告4～7され ているが，日本国内ならびに米国における製造経験は極 めて少ない.

そこで，本報では $16.5 \mathrm{Cr}-4 \mathrm{Ni}$ 鋼を基本に耐食性の優 れたランナー材組成を決定するとともに, 大型ランナー 部分モデルを製造し, 内部性状, 機械的性質等水車ラン ナーに要求される品質を評価した.

\section{2. 化学成分の選定}

\section{$2 \cdot 1$ 供試材および実験方法}

\section{$2 \cdot 1 \cdot 1$ 供試材之熱処理}

供試材は $16.5 \mathrm{Cr}-4 \mathrm{Ni}$ 鋼を基本組成に $\mathrm{Cr}, \mathrm{Cu}, \mathrm{Mo}$ を変動因子とし，他成分は工業的レベルで一定とした。 このような鋼種は高周波誘導炉にてそれぞれ $50 \mathrm{~kg}$ 溶製 して自硬性砂型に鋳込んだ. 得られた化学成分をTable 1 亿示す. 熱処理は鋳造組織の均質化, 炭化物の固溶な らびに結晶䊀の微細化の点から, $1050^{\circ} \mathrm{C}$ 焼鈍 $+950^{\circ} \mathrm{C}$ 焼準を行い，焼もどしは $600^{\circ} \mathrm{C}$ と $630^{\circ} \mathrm{G}$ で行つた。

\section{$2 \cdot 1 \cdot 2$ ミク口組織観察之機械試験}

ミクロ組織は供試材を研磨後酸性ピクリン酸エッチし 光学影微鏡観察した. 引張試験はインストロン型引張試

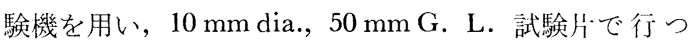
た.ここで歪み速度は $0.5 \%$ まで $0.3 \% / \mathrm{min}$ で試験し た.また，シャルピー衝撃試験はJIS 4 号 $2 \mathrm{mmV}$ ノッ

Table 1. Chemical composition range of laboratory made castings (wt \%).

\begin{tabular}{|c|c|c|c|c|c|c|c|c|}
\hline C & $\mathrm{Si}$ & $\mathrm{Mn}$ & $\mathrm{P}$ & $S$ & $\mathrm{Ni}$ & $\mathrm{Cr}$ & $\mathrm{Cu}$ & Mo \\
\hline $0.04^{*}$ & $0.30^{*}$ & $0.75^{*}$ & $0.015^{*}$ & $0.020 *$ & $\begin{array}{l}3.75 \\
6.10\end{array}$ & $\begin{array}{l}12.30 \\
17.50\end{array}$ & $\frac{10.05}{1.10}$ & $\begin{array}{l}0.01 \\
1.00\end{array}$ \\
\hline
\end{tabular}

* Mean value

昭和 58 年 10 月本会講演大会にて発表 昭和 58 年 10 月 18 日受付 (Received Oct. 18, 1983)

* (株) 日本製鋼所室蘭製作所 (Muroran Plant, The Japan Steel Works Ltd., 4 Chatsu-cho Muroran 051)

*2（株）日本製鋼所室蘭製作所 工博 (Muroran Plant, The Japan Steel Works Ltd.) 
チシャルピー衝撃試験片を用い， $-100^{\circ} \sim 200^{\circ} \mathrm{C}$ で行

つた.

\section{$2 \cdot 1 \cdot 3$ 疲労試験}

小野式回転曲げ疲労試験機を用い，平滑ならびに $K_{\mathrm{t}}$ $=2.5$ の切り欠き試験片により海水滴下条件, 繰り返し 速度 $1500 \mathrm{rpm}$ で行つた.

$2 \cdot 1 \cdot 4$ キャビテーションエロージョン試験

$500 \mathrm{~W}$ 超音波エロージョン試験機（島田理化工業製二 ッケル積層ホーン形）を用い，振動数 $6.5 \pm 0.05 \mathrm{kHz}$, 振幅 $50 \sim 90 \mu \mathrm{m}$, 室温水道水中（液深: $110 \mathrm{~mm}$, 試験片 浸漬深度 : $3 \mathrm{~mm}$ ) で $30 \mathrm{~min} こ ゙ と ， 4$ 回 $120 \mathrm{~min}$ 試験 し重量減を測定した。

\section{$2 \cdot 1 \cdot 5$ アノード分極測定}

供試材はエメリー紙でキ800 まで研磨し，10×10 mm の試験面以外は樹脂で被覆した. 電解液は $1 \mathrm{NH}_{2} \mathrm{SO}_{4}+$ $20000 \mathrm{ppm} \mathrm{Cl}$ - で, 照合電極は甘こう電極を用いた。ア

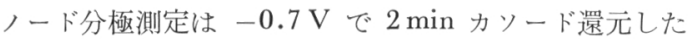
のち, 電位掃引速度 $100 \mathrm{mV} / \mathrm{min}$ で行つた。

\section{$2 \cdot 2$ 結果および考察}

Photo. 1 に各供試材のミクロ組織を示す. いずれも 基地は焼もどしマルテンサイトであるが， $13 \mathrm{Cr}-4 \mathrm{Ni}$ 以 外は数\%〜20\%のデルタフェライトを含んでいる.こ のよらなデルタフェライト量と化学成分との関係につい ては多くの報告があり，オーステナイト系ステンレス鋳 鋼の場合は SCHAEFFLER の状態四 ${ }^{8}$ により，デルタフェ
ライト量は比較的良好な精度で求めることができる9). 一方，マルテンサイトステンレス鋳鋼ではデルタフェラ イト量を化学成分から定量的に推測することは難しい が，Fig. 1 に示すように $\mathrm{Ni}$ 当量の低下または $\mathrm{Cr}$ 当 量の上昇により，デルタフェライトが増加することが SGHNEIDER ${ }^{10)}$ 図から明らかである.

各試料の引張り括よび衝撃性質を Fig. 2 に示す. 強 度㧍よび延性は Cr，Ni，Mo 量にあまり依存せず，約 $80 \mathrm{~kg} / \mathrm{mm}^{2}$ の引張強さレベルで十分な延性を有してい るが, 衝撃值は Cr 当量の高い試料汪ど低くなる傾向が 認められる.これは Fig. 3 の衝撃值とデルタフェライ 卜量の関係で示されるように, 衝撃值の低下はデルタフ

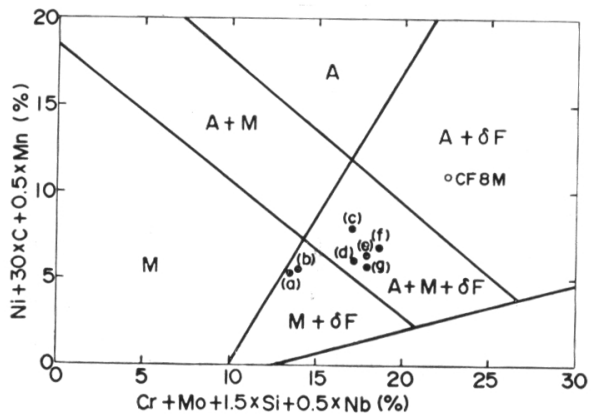

Fig. 1. Schneider diagram for showing the effect of chemistry on the phase, (a) $13 \mathrm{Cr}-4 \mathrm{Ni}-0.45 \mathrm{Mo}$ (b) $13 \mathrm{Cr}-4 \mathrm{Ni}-0.5 \mathrm{Mo}-1 \mathrm{Cu}$, (c) $16.5 \mathrm{Cr}-6 \mathrm{Ni}$, (d) $16.5 \mathrm{Cr}-4.5 \mathrm{Ni}$, (e) $16.5 \mathrm{Cr}-4.5 \mathrm{Ni}-1 \mathrm{Mo}$, (f) $17 \mathrm{Cr}-$ $5 \mathrm{Ni}-1 \mathrm{Mo}, \quad$ (g) $17 \mathrm{Cr}-4 \mathrm{Ni}-0.45 \mathrm{Mo}-1 \mathrm{Cu}$.
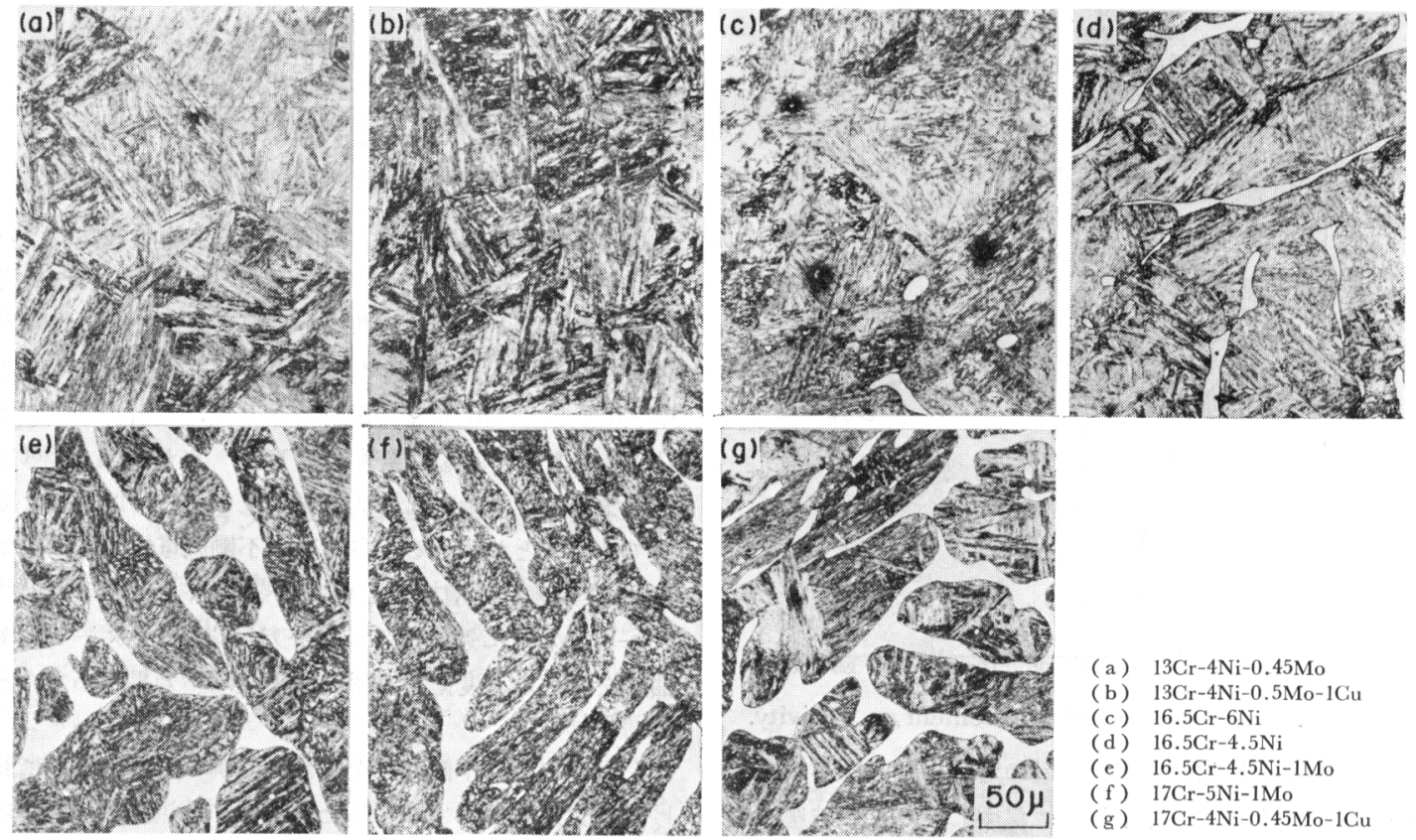

(a) $13 \mathrm{Cr}-4 \mathrm{Ni}-0.45 \mathrm{Mo}$

(b) $13 \mathrm{Cr}-4 \mathrm{Ni}-0.5 \mathrm{Mo}-1 \mathrm{Cu}$

(c) $16.5 \mathrm{Cr}-6 \mathrm{Ni}$

(d) $16.5 \mathrm{Cr}-4.5 \mathrm{Ni}$

(e) $16.5 \mathrm{Cr}-4.5 \mathrm{Ni}-1 \mathrm{Mo}$

(f) $17 \mathrm{Cr}-5 \mathrm{Ni}-1 \mathrm{Mo}$

(g) $17 \mathrm{Cr}-4 \mathrm{Ni}-0.45 \mathrm{Mo}-1 \mathrm{Cu}$

Photo. 1. Microstructures of different martensitic stainless cast steels normalized and tempered. 

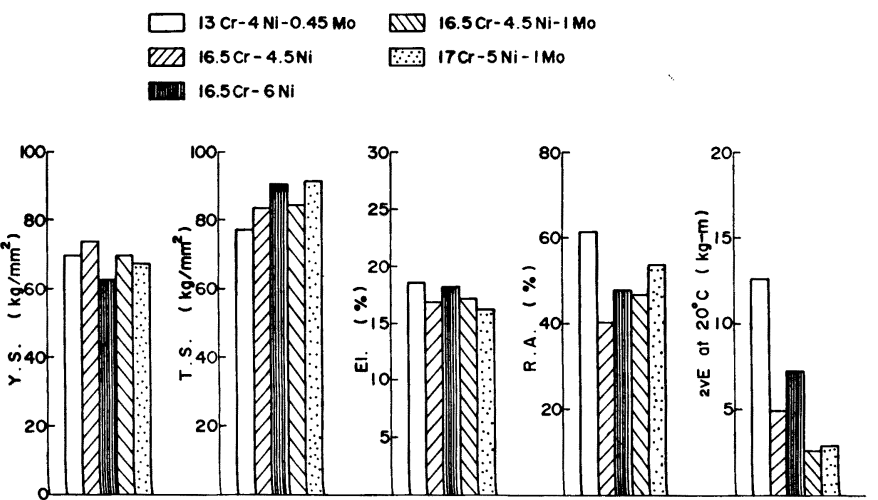

Fig. 2. Comparison of mechanical properties.

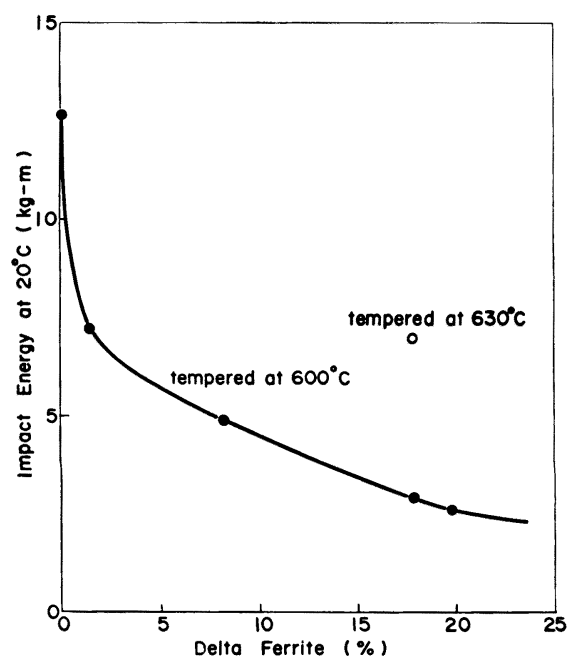

Fig. 3. Effect of delta ferrite on impact energy.

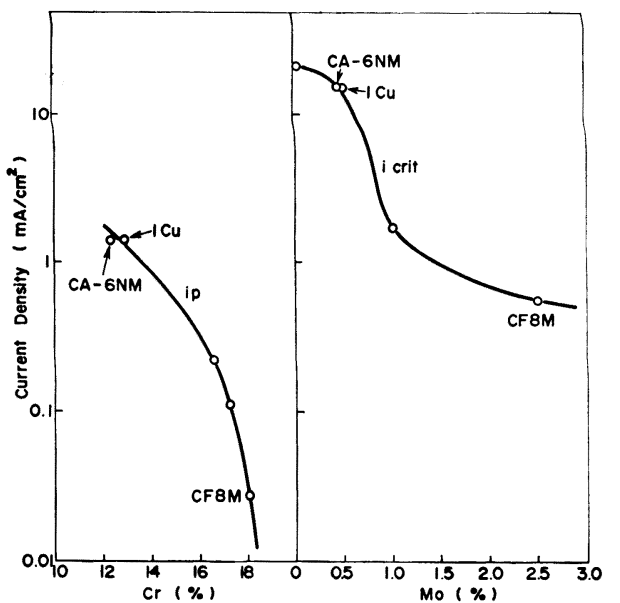

Fig. 4. Effect of $\mathrm{Cr}$ and Mo content on passivity.

ェライト量の増加に起因するもので, 衝撃歪みが軟質層 であるデルタフェライト界面に集中し，へき開破壊単位 が大さくなるためと考觉られる。

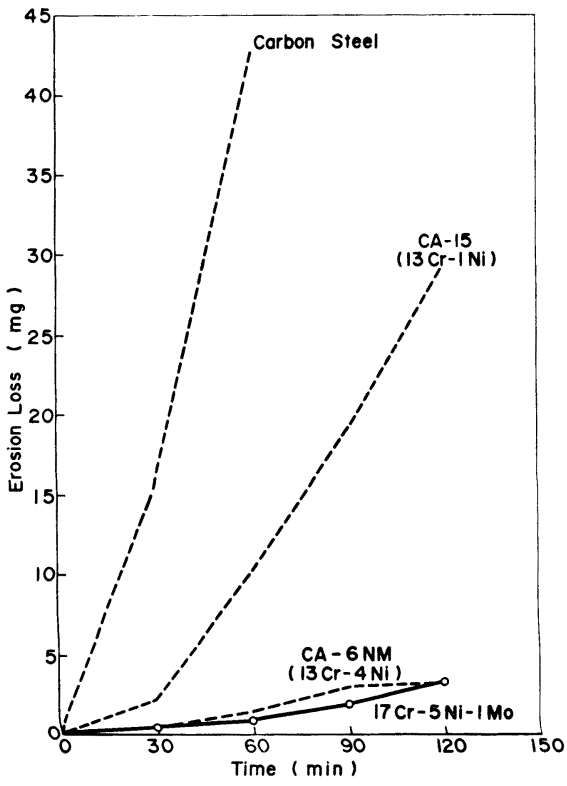

Fig. 5. Cavitation erosion loss vs. elapsed time.

次に本試験における最大の関心事である耐食性につい ては電気化学特性により評価した. Fig. 4 は定電位法 で測定したアノード分極曲線から得られる不働態化臨界 電流密度 $\left(i_{\text {crit }}\right)$ および 不働態化保持電流密度 $\left(i_{\mathrm{p}}\right)$ と $\mathrm{Cr}$ 量または Mo 量との関係を示した。これから, $i_{\mathrm{p}}$ は $\mathrm{Cr}$ 量の増加とともに顕著に低下し，また $i_{\mathrm{crit}}$ は $1 \%$ Mo までは涯加量による低下が大きく，それ以上では緩 慢であることがわかる，さらに，不働態電位域も $\mathrm{Cr}$ な らびに Mo 量の増加とともに広くなり, CF8M (19Cr9Ni-2.5Mo) に近くなるが，一方，Cu はアノード分極 曲線をほとんど変えず，耐食性に及ぼす効果は小さいと 判断される.

したがつて，不働態化を容易にしかつ不働態状態にお ける腐食速度を小さくするためには，Cr 量の増加なら びに $1 \%$ 程度の Mo 添加が必要であることがわかつ 


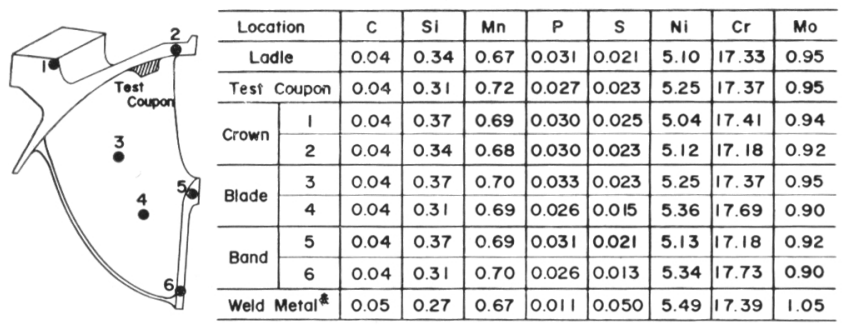

- Shield arc electrode $\left(4 \mathrm{~mm}^{\star}\right)$

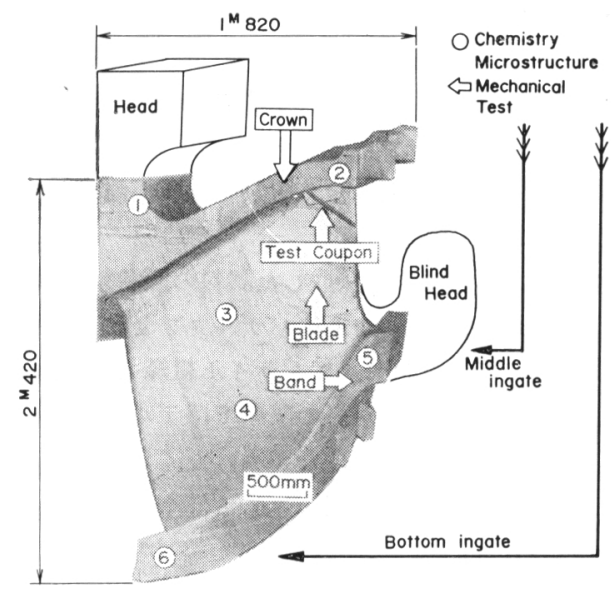

Photo. 2. Casting design and general view of a partial model runner casting.

た. 他方，Fig. 3 に示されているよらに， Gr ならびに Mo 量の増加は Cr 当量を高めデルタフェライト量を増 加させ衝撃性質が低下するので好ましくないが，勒性は 焼もどし温度を $630^{\circ} \mathrm{C}$ にすることにより改善され(Fig. 3), 本試験では耐食性を向上させ GF8M 相当にするこ とを最大のポイントに置き， $17 \mathrm{Cr}-5 \mathrm{Ni}-1 \mathrm{Mo}$ 鋳鋼を選定 した。

なお， 17Cr-5Ni-1Mo 鋳鋼のキャビテーションエロ ージョン性質は Fig. 5 に示すように CA-6NM に匹敵 するものであり，ランナー材料之して十分満足するもの である・

\section{3. 水車ランナー部分モデルの評価}

\section{$3 \cdot 1$ 製造要領および試験}

供試鋳鋼は $200 \mathrm{MW}$ 級大型フランシスランナーのブ レード 1 枚分を分割した形状で, Crown, Blade, Band とともに実機サイズを有する部分モデルであり，10 t 塩 基性電気炉にて溶製しクロマイト砂自硬性砂型に鋳込ん た. 得られた化学成分を Table 2 に示す. Photo. 2 は 供試部分モデルの概略鋳造方案と熱処理後の外観を示し
Table 2. Chemical composition of a model casting (wt \%).

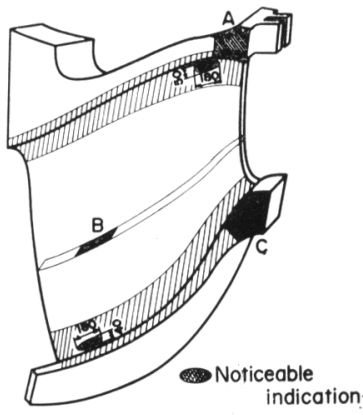

(a). N D I (UT)

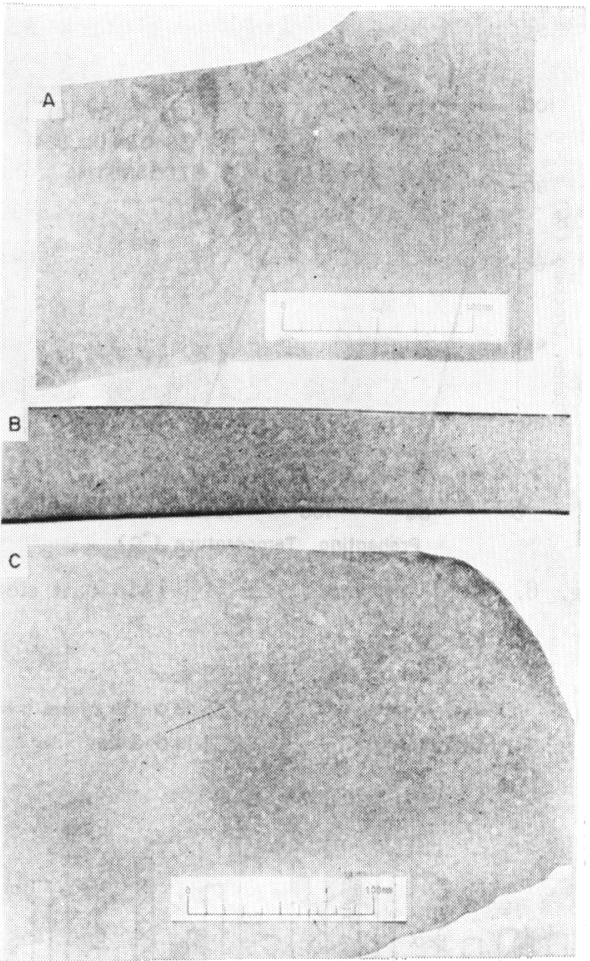

(b). Macrostructure

Photo. 3. UT indication and macrostructures at the cross sections of crown, blade and band in a model runner casting. 
たもので，シュリンケージキャビティを低減する目的か ら Crown 上部と Blade に押湯を設けるとともに，鋳込 速度を一定に保つため下段，中段，2箇所のせさから鋳 込ん3)12) だ. 熱処理は 2.2 の結果に基づき押湯をガス切 断除去した後に， $1050^{\circ} \mathrm{C} \times 10 \mathrm{~h} \rightarrow$ 炉冷 $\rightarrow 950^{\circ} \mathrm{C} \times 10 \mathrm{~h} \rightarrow$ 衝風冷却 $\rightarrow 630^{\circ} \mathrm{C} \times 10 \mathrm{~h} \rightarrow$ 炉冷を施した。次いで，実機 における補修溶接後の SR を考虑し,さらに $600^{\circ} \mathrm{C} \times 10$ $\mathrm{h} \rightarrow$ 炉冷を行い試験に供した.

試験は超音波探傷試験（UT)，マク口腐食試験を行つ た後各部より採取した試験片を用いて，化学分析による 偏析調査, 組織観察, 引張試験, 衝撃試験, アノード分 極測定，小野式回転曲げ腐食疲労試験および斜めY 型拘 束溶接割れ試験を行つた。ここで，各試験方法の詳細は $2 \cdot 1$ に述べたとおりで，試験位置および試験片採取位置 はPhoto. 2 に併記した。な拈，超音波探傷試験は B2SN, MB2SN と MWB45N2 探触子を用い, $2 \mathrm{MH}_{Z}$ で垂直ならびに斜角により行つた。また，斜めY型拘束 試験は JIS Z 3158 に準拠し，Table 2 に示した $4 \mathrm{~mm} \phi$ 共金溶接棒を用い, $25^{\circ} \sim 75^{\circ} \mathrm{C}$ の予熱条件で試験ビー ド溶接を行つた.

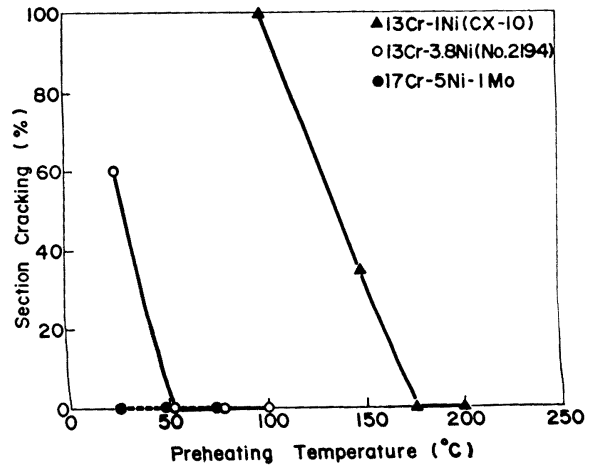

Fig. 6. Weldability of $17 \mathrm{Cr}-5 \mathrm{Ni}-1 \mathrm{Mo}$ cast steel.

\section{2 結果および考察}

$3 \cdot 2 \cdot 1$ モデルランナーの健全性と溶接性

モデルランナーの外観（Photo. 2) から明らかなよう に，鋳造性低下に起因するような表面欠陥（例觉ば湯じ わ，砂かみ，ブローホール）は認められず，また各部位 の化学成分は Table 2 に示したように, Crown, Blade, Band ならびに Test Coupon とも均一であり, 合 金成分の偏析は認められない。

Crown ならびに Band の付根部について行つた UT の結果と各断面のマクロ腐食組織を Photo. 3 に示す. UT 欠陥はすべてミクロキャビティであり付根の一部の みしか認められず，またマク口組織は凝固冷却速度の遅 いCrown 側では一次晶が幾分粗くなつているが，逆 $\mathrm{V}$ ならびにV偏析やき裂は全く観察されず，健全なランナ 一であることが確認された。

Photo. 4 に各部より採取した試料の顕微鏡組織を示 す. 写真から明らかなように，デルタフェライトを 15 \% 前後含む焼もどしマルテンサイト組織であり, 厚肉を 有する Crown, Band からの試料ではデルタフェライト が粗く分布しているが大きな差異はなく, 前述したUT ならびにマクロ組織の結果とともに健全なランナーであ ることがわかる。

次に，鋳鋼品として不可避的に生じる鋳造欠陥の補修 に対して要求される溶接性に関して, 斜め $\mathrm{Y}$ 型拘束割れ 試験結果を予熱温度と断面割れ率の関係で Fig. 6 に示 す. 従来ランナー材料として用いられている $13 \mathrm{Cr}-\mathrm{Ni}$ 系鋳鋼 ${ }^{12}$ )では $1 \mathrm{Ni}^{3}$ ) の場合 $125^{\circ} \mathrm{C}$ 以下で， また $4 \mathrm{Ni}$ では $50^{\circ} \mathrm{C}$ 以下においては冷間割れが発生するが，本鋼 では室温まで全く割れを生じていないことから溶接性の 優れた鋳鋼であると言える。

$3 \cdot 2 \cdot 2$ モデルランナーの機械的性質と耐食性

モデルランナー各部より採取した試料の機械的性質を

Fig. 7 に示す. 引張強さならびに降伏応力ともほとん

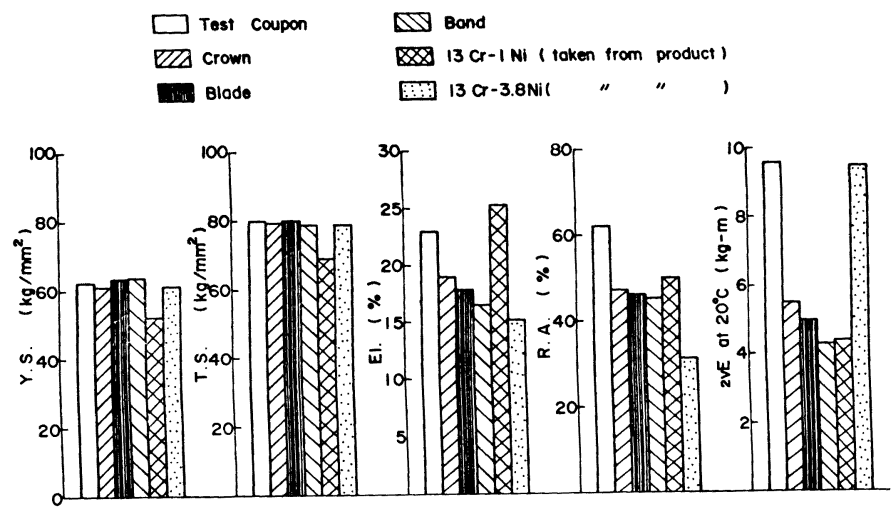

Fig. 7. Mechanical properties of the specimens taken from each location of a model runner casting. 
ぞ採取位置による差はない, しかし，伸び，絞りおよび 衝撃值は Test Coupon が最も高い值を示し, 他はそれ よりも低い傾向を示すが Crown, Blade, Band におけ る差は小さい。このような Test Coupon と本体との靫 延性の相違は凝固冷却速度に起因寸るもので, 本体試料 のミクロポロシティ存在頻度ならびにデルタフェライト 量が多く，また粗大であることが影響しているものと推 測される.ここで, 従来より水車ランナー材として使用

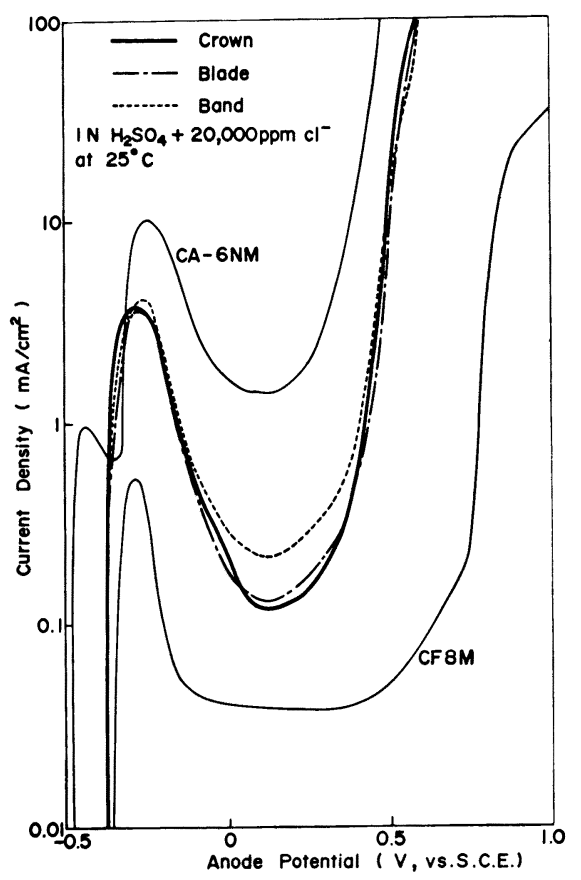

Fig. 8. Potentiostatic polarization curves of the specimens taken from each location of a model runner casting in $1 \mathrm{NH}_{2} \mathrm{SO}_{4}+\mathrm{Cl}$-solution.
されている $\mathrm{CA}-15^{3)}$ ならびに CA-6NM212) と機械的 性質を比較してみると，Fig. 7 に示されているように， 強度延性は CA-6NM と同等であるが，多量に含まれる デルタフェライトにより衝撃值は GA-15 に近い值を有 していることがわかる.

Fig. 8 は各部より採取した試料のアノード分極曲線 で，小型試料による結果同様， $i_{\mathrm{p}}, i_{\text {crit }}$ は GA-6NMと CF8M の中間に位置するものであり，また各試料の 差も小さく，優れた耐食性を有することが確認された.

ところで, 水車ランナー材として重要な疲労強度につ いては, 本試験の場合腐食環境を考慮して海水滴下条件 で行い， CF8M ならびに CA-6NM と比較検討した。 この結果を Fig. 9 に示す. 図から明らかなように切り 欠き効果も小さく, また $K_{\mathrm{t}}=2.5$ の切り欠き疲学強度 は $10^{7}$ サイクルで比較すると $13 \mathrm{~kg} / \mathrm{mm}^{2}$ 以上あり, GF8M やCA-6NM に比べ 10〜20\% 高い疲労寿命を 有していることが確認された。これは CA-6NM に対 して Cr 量を増加し，かつ Moを $1 \%$ 添加することに よつて耐食性が向上し，またマルテンサイトステンレス 鋼であることから CF8M よりもはるかに高い強度が得 られることによるものと推測される.

\section{4. 結 言}

耐食性および腐食疲労強度の優れた水車ランナーの開 発を目的に，小型試料で化学成分の選定を行い種々検討 するとともに, $17 \mathrm{Cr}-5 \mathrm{Ni}-1 \mathrm{Mo}$ 鋳鋼大型ランナー部分 モデルを製造し，内部健全性，機械的性質等について調 查検討した。得られた結果を要約すると次のとおりであ る.

（1）超音波探傷試験, マク口腐食組織ならびに化学

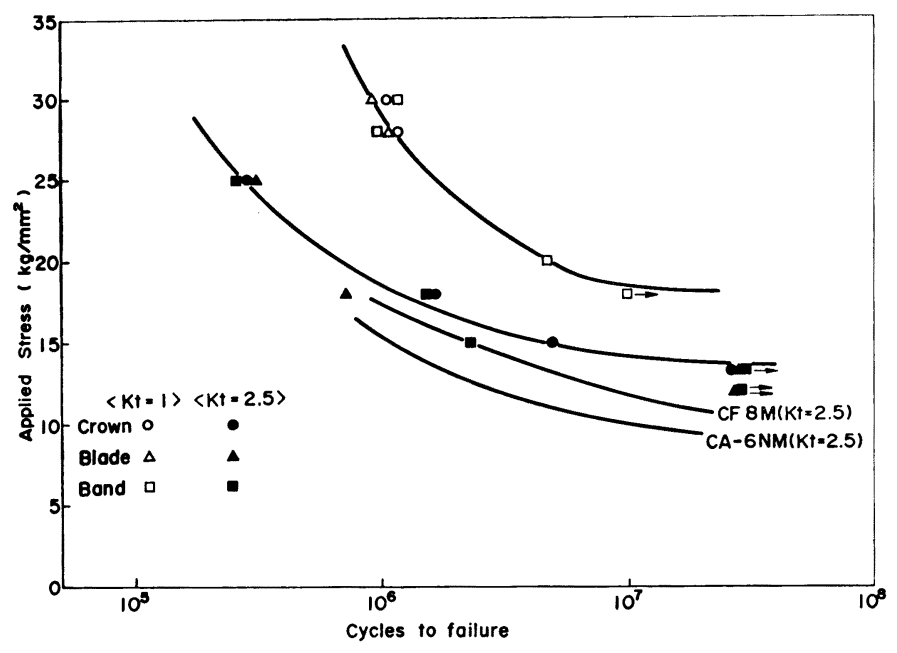

Fig. 9. S-N curves in sea water for the specimen taken from each location of a model runner casting. 

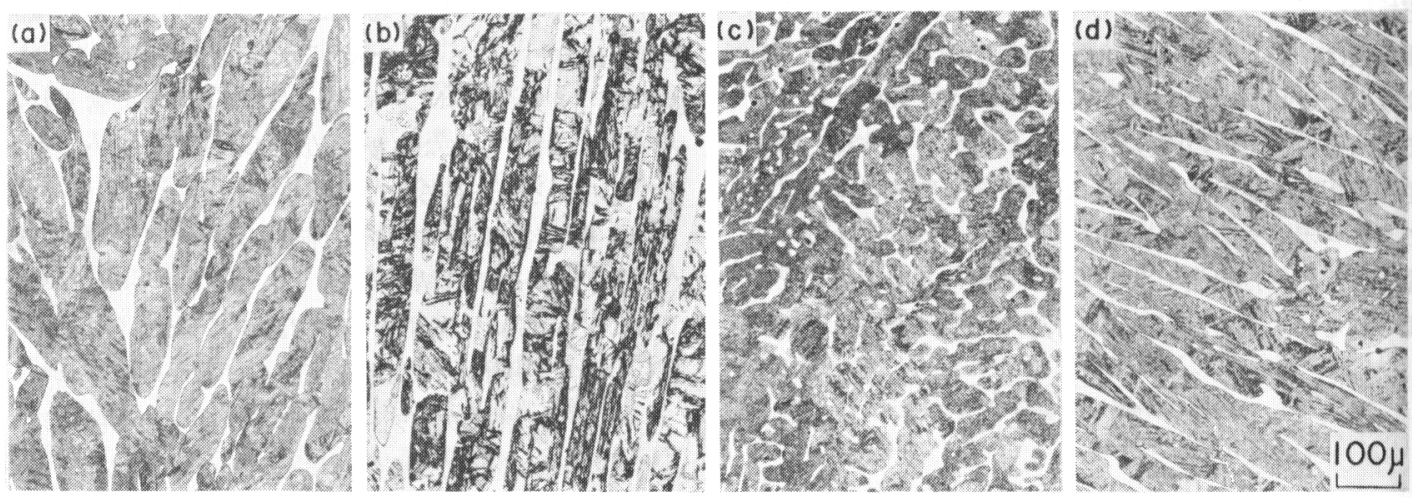

(a) Crown, (b) Blade, (c) Band, (d) Test Coupon

Photo. 4. Microstructures at several locations of a model runner casting.

分析などの結果から，内部性状は $13 \mathrm{Cr}-\mathrm{Ni}$ 系鋳鋼ラン ナー同様比較的良好であることが判明した。

(2) 質量効果は小さく, 必 $13 \mathrm{Cr}-4 \mathrm{Ni}$ と同程度 の引張り性質が得られるが,デルタフェライトを約 $15 \%$ 含む燒もどしマルテンサイトであるため, 衝撃性質は 13 Cr-1Ni なみである。

（3）優れた耐食性は $\mathrm{Cr}$ 量の增加と Mo 添加によ り達成され, また高い腐食疲労強度は耐食性の向上之高 强度により得られるものと推定される。

（4）斜めY型拘束割礼試験から，予熱なしでも溶接 冷間割孔が起こらないことが確認された。

（5）従来水車ランナー材として使用されている 13 $\mathrm{Cr}-1 \mathrm{Ni}$ 打よび $4 \mathrm{Ni}$ 鋳鋼に比較して, 本実験の $17 \mathrm{Cr}-$ $5 \mathrm{Ni}-1 \mathrm{Mo}$ 鋳鋼ランナーは製造性ならびに製造要領が同 等であるのに対して, 耐食性, 腐食疲労強度が極めて優 れていることから，腐食環境の厳しい河川などに抢ける 水車ランナー材として，十分炎の使用が可能と考兄られ る.

\section{交献}

1) 德田 昭, 熊田有宏, 中川嘉一: 日本製鋼所技報, 21 (1970), p. 3142

2) $Y$. Iwabuchi and $S$. Sawada: ASTM STP 756 (1982), p. 332

3 ) $Y$. Iwabuchi and $K$. Suzuki: AFS Transaction, 41 (1982), p. 411

4) N. F. Моiт: Iron Age, 171 (1953) 24, p. 125

5 ) G. E. Linnert: Welding J., 36 (1957) 1, p. 9

6 ) P. Brezina: Escher-Wyss-Mitteilungen, 1 (1980) 2, p. 218

7 ) $H . J$. Niederau: ASTM STP 756 (1982), p. 382

8 ) A. L. Schaeffler: Metal Progress, 56 (1949), p. 680

9 ) 田辺潤平，板坦純司：日本製鋼所技報，30(1979), p. 13

10) H. Schneider: Foundry Trade J., 108(1960), p. 562

11) 柴田俊夫：防食技術，18(1969) 9, p. 415

$12) N$. Hiraoka, $K$. Watanabe, $T$. Miyamoto, and S. Jin: JSW Technical Review, (1977) 13 , p. 23 